\title{
CHARACTERIZATION OF TWO LOW-CHARGE VERMICULITES AFTER HYDROCHLORIC ACID TREATMENT
}

\author{
Jana KUPKOVÁ ${ }^{1,2) *}$, Dominik HONĚK ${ }^{1)}$, Silvie VALLOVÁ ${ }^{3)}$ and Marta VALÁŠKOVÁ ${ }^{1,2)}$
}

\author{
${ }^{1)}$ Nanotechnology Centre, V̌̌B-Technical University Ostrava, 17. listopadu 15, Ostrava, 708 33, Czech Republic \\ ${ }^{2)}$ IT4Innovations Centre of Excellence, VŠB-Technical University of Ostrava, 17. listopadu 15, Ostrava, Czech Republic \\ ${ }^{3)}$ Department of Chemistry, VŠB-Technical University of Ostrava, 17. listopadu 15, Ostrava, Czech Republic
}

*Corresponding author's e-mail: jana.kupkova@vsb.cz

\section{ARTICLE INFO}

Article history:

Received 24 March 2015

Accepted 29 May 2015

Available online 13 July 2015

Keywords:

Vermiculite

Hydrochloric acid treatment

X-ray diffraction

Thermal analysis

Surface area measurement

\begin{abstract}
Two natural vermiculites (Ver) with very similar chemical composition but slightly different low charge on the layers were investigated to find an answer the question, how to change their structural and chemical properties after exposure to different concentrations of $\mathrm{HCl}$ solutions. Vermiculite from Bulgaria (Ver-B) with the layer charge $0.47 \mathrm{eq} / \mathrm{O}_{10}(\mathrm{OH})_{2}$ and from Brazil (VerSL) with the layer charge $0.36 \mathrm{eq} / \mathrm{O}_{10}(\mathrm{OH})_{2}$ were studied on their particle size fraction less than $40 \mu \mathrm{m}$ after treatment at different $\mathrm{HCl}$ concentrations $(0.5 \mathrm{M} \mathrm{HCl}$ and $1 \mathrm{M} \mathrm{HCl})$. Both samples represent a mixed-layer structure after incomplete transformation of mica (biotite) to vermiculite. Based on the XRD patterns, Ver-B may be considered as the mixed-layer vermiculite interstratified with small proportion of mica layers and Ver-SL as the mixed-layer micavermiculite. The leaching with $0.5 \mathrm{M} \mathrm{HCl}$ increased SA of Ver-B from $29.5 \mathrm{~m}^{2} . \mathrm{g}^{-1}$ to $261 \mathrm{~m}^{2} . \mathrm{g}^{-1}$ at Ver-B05 in comparison with the SA of Ver-SL from $14.0 \mathrm{~m}^{2} \cdot \mathrm{g}^{-1}$ to $191 \mathrm{~m}^{2} \cdot \mathrm{g}^{-1}$ in Ver-SL05. It can be assumed that the acidification was more effective to: (1) leaching of $\mathrm{Mg}^{2+}$ cations at incomplete vermiculated sample Ver-SL and (2) $\mathrm{Fe}^{2+}$ and $\mathrm{Fe}^{3+}$ from octahedra and $\mathrm{Al}^{3+}$ from the tetrahedra at vermiculite sample Ver-B and (3) increasing SA at Ver-B.
\end{abstract}

\section{INTRODUCTION}

Acid hydrolysis reactions of many different clay minerals have been investigated as routes to high surface area of silicates with properties well suited as adsorbents, catalysts, and composite filling materials. Octahedral cations such as $\mathrm{Al}^{3+}, \mathrm{Fe}^{3+}, \mathrm{Fe}^{2+}$, and $\mathrm{Mg}^{2+}$ can be depleted by treating the clay minerals with acids at elevated temperatures. Various types of inorganic $\left(\mathrm{HCl}, \mathrm{HNO}_{3}, \mathrm{H}_{2} \mathrm{SO}_{4}\right)$ or organic (acetic, citric, oxalic acid) acids may be used for acid treatment. Hydrochloric acid $(\mathrm{HCl})$ is among the most widely used in acid activation of clay minerals due to its good results in increased values of the surface area, porosity and adsorption capacity (Kumar et al., 2013). Treatments of clay minerals with acid solutions (acid activation, selective leaching) represent useful methods for the preparation of materials with high surface area or porous silica. The extent of the decomposition of their structure depends on the type of clay minerals, the nature of octahedral and tetrahedral cations, temperature, treatment time and type and concentration of acid (Maqueda et al., 2008). In acid treated materials, the sorptive properties are enhanced, the surface acidity, surface area, porosity and pore volume are increased (Jin and Dai, 2012).

Vermiculites are phyllosilicates that originate from alteration of mica-type minerals and, less commonly, from amphiboles and chlorites (Schoeman, 1989). Therefore, natural 'vermiculites' are not all pure Mg-vermiculite members but also mixed-layer phyllosilicates, such as biotite-vermiculite, phlogopite-vermiculite or vermiculite-chlorite (Moore, 1997). Mg-vermiculites are expandable 2:1 hydrous phyllosilicates consisting of the two tetrahedral sheets and one octahedral sheet located between tetrahedral sheets. The chemistry of vermiculites is closely linked to that of mica. The differences are based on the lower layer charge and the iron oxidation in comparison with the mica. Reduction of charge is related to the oxidation of iron. The negative layer charge, which arises mostly from the substitution of $\mathrm{Al}^{3+}$ for $\mathrm{Si}^{4+}$ in tetrahedral sites, is between 0.6 and $0.9 \mathrm{eq} /(\mathrm{Si}, \mathrm{Al})_{4} \mathrm{O}_{10}$. Several observations suggest that vermiculitization is not the final stage of alteration. A continuous process of mica-vermiculite-smectite alteration results in vermiculites that show a smectite charge. The excess layer charge is compensated by the hydrated exchangeable cations such as $\mathrm{Mg}^{2+}, \mathrm{Ca}^{2+}$, $\mathrm{Na}^{+}$and $\mathrm{K}^{+}$that occupy the interlayer space (Guggenheim et al., 1997; Brigatti et al., 2006). The charge and cation radius affect the stacking layer sequence and the degree of hydration in the interlayer. The interlayer space saturated by bivalent cations exhibits one or two water layers depending on the relative humidity (Meunier, 2005). Pure Mgvermiculite contains up to two sheets of interlayer water (Shirozu and Bailey, 1966). The basal space of $\mathrm{Mg}$-vermiculite was reported as $1.440 \mathrm{~nm}$ for the two- 
water-layer hydration state, $1.150 \mathrm{~nm}$ for one-waterlayer and $0.902 \mathrm{~nm}$ for the no-water-layer phase (Walker, 1956).

Suquet et al. (1991) and Temuujin et al. (2003) investigated the influence of $\mathrm{HCl}$ concentrations and leaching time on vermiculite to prepare porous silica with high surface area. The optimal conditions for preparation of such material was $2 \mathrm{M} \mathrm{HCl}$ at $80^{\circ} \mathrm{C}$ for $2 \mathrm{~h}$. Likewise, Temuujin et al. (2008) studied the effect of calcination at $600{ }^{\circ} \mathrm{C}$ for $2 \mathrm{~h}$ in combination with $\mathrm{HCl}$ treatment $\left(2 \mathrm{M}, 80^{\circ} \mathrm{C}\right.$ for $0.5,2$ and $\left.8 \mathrm{~h}\right)$. The highest value of the surface area was obtained for the sample leached for $8 \mathrm{~h}$. Maqueda et al. (2008) prepared amorphous silica after 4 min of grinding in combination with leaching in $1 \mathrm{M} \mathrm{HCl}$. PérezMaqueda et al. (2012) investigated the thermal behaviour of raw and ground vermiculite leached with $\mathrm{HCl}$ and found differences in crystallization of mineral phases for unground, acid-treated vermiculite (dehydrated vermiculite, enstatite and cristobalite) and for ground, acid-treated vermiculite (iron oxides and cristobalite). Santos et al. (2015) prepared porous layered structures of high surface area (673 and $628 \mathrm{~m}^{2} \cdot \mathrm{g}^{-1}$ ) by treatments of two vermiculites at various concentrations of nitric acid $\left(80{ }^{\circ} \mathrm{C}, 4 \mathrm{~h}\right)$. Formation of such highly porous materials after treatment with $\mathrm{HNO}_{3}$ was more effective after a shorter period in comparison to $\mathrm{HCl}$ and/or $\mathrm{H}_{2} \mathrm{SO}_{4}$ treatments.

Micas as starting materials in weathering series are thought to be homogeneous with nearly with same cation density in all interlayer spaces. Smectites as weathering products generally have heterogeneous charge distributions, similar to those found in mixedlayer minerals. Vermiculites represent initial stages in the alteration sequence of micas and their charge heterogeneity should correspond to the fundamental processes of weathering (Lagaly, 1982). The chemical composition of vermiculites can be similar while their layer charge is different. For example, Wiewióra et al. (2003) documented different effects in the particle morphology between the low- and high-charge vermiculites with the similar chemical composition during sonication.

Two vermiculites from Bulgaria and Brazil with the very similar chemical composition but slightly different layer charge examined in this work were investigated by Valášková et al. (2013a; 2013b; 2014). Therefore the aim is to find an answer the question, how to change their structural and chemical properties after exposure to different concentrations of hydrochloric acid solutions.

\section{MATERIALS AND METHODS \\ 2.1. MATERIALS}

Two natural vermiculites (Ver) (supplied by Grena, Ltd., Czech Republic) from the Belitsa (Ver-B) deposit in northern Bulgaria (Seghedi, 2012) and from the Santa Luzia (Ver-SL) deposit in the Paraiba region of Brazil (Alves et al., 2013) were chosen for samples preparation. The samples Ver-B and Ver-SL were mechanically milled in a vibratory mill VM4 (Czech Republic) at $1500 \mathrm{rpm}$ for $2.5 \mathrm{mn}$. The particle size fraction smaller than $40 \mu \mathrm{m}$ was obtained by sieving for further experiments. An aqueous solution of 37 wt.\% hydrochloric acid ( $\mathrm{HCl})$, from SigmaAldrich, Ltd., Czech Republic was used for acid activation.

\subsection{CHARACTERIZATION METHODS}

The chemical composition was determined using the X-ray fluorescence spectrometer Spectro X-lab (Spectro Analytical Instrument, Germany). The samples were mixed with the wax and pressed into the form of pellets. The concentration of $\mathrm{Na}^{+}, \mathrm{K}^{+}, \mathrm{Mg}^{2+}$ and the total content of the $\mathrm{Fe}^{2+}$ and $\mathrm{Fe}^{3+}$ was also determined using the atomic emission spectrometer JY 24 with inductively coupled plasma (ICP-AES) (Spectro Analytical Instrument, Germany) after total sample dissolution in $\mathrm{HCl}$ and $\mathrm{HF}$ and acid mixture $\left(\mathrm{H}_{3} \mathrm{PO}_{4}+\mathrm{H}_{2} \mathrm{SO}_{4}+\mathrm{H}_{3} \mathrm{BO}_{3}\right)$ (Seidlerová et al., 2007). The content of $\mathrm{Fe}^{2+}$ was determined using titration with $0.1 \mathrm{M}$ solution of $\mathrm{K}_{2} \mathrm{Cr}_{2} \mathrm{O}_{7}$ after sample decomposition in $\mathrm{HCl}$ and $\mathrm{HF}$ in a $\mathrm{CO}_{2}$ atmosphere, according to the Czech standard CSN 722041 Part 11. The loss on ignition was determined by heating of samples in muffle furnace at $1000^{\circ} \mathrm{C}$.

$\mathrm{X}$-ray powder diffraction analysis was performed using the X-ray diffractometer Ultima IV Rigaku (Rigaku, Japan), operated at $40 \mathrm{kV}$ and $40 \mathrm{~mA}$ with $\mathrm{CuK} \alpha$ radiation (reflection mode, scintillation counter). The XRD patterns were recorded in the $8-$ $80^{\circ} 2 \theta$ range with a scanning rate of $2 \% \mathrm{~min}$. The samples were placed in a ground glass depression in the sample holder and flattened with a glass slide. Xray beam was demarcated by $2 / 3^{\circ}$ divergence, $10 \mathrm{~mm}$ divergent height limiting, $2 / 3^{\circ}$ scattering and $0.45 \mathrm{~mm}$ receiving slits.

The measurement of surface area (SA) was performed with a Sorptomatic 1990 (Thermo Electron Corporation, USA) apparatus at liquid-nitrogen temperature. Nitrogen gas was used as an adsorbate. The SA was calculated by the Advance Data Processing software according to the Branauer, Emmett and Teller method.

The thermal properties of original and acidified vermiculites were investigated by simultaneous thermogravimetry (TG) and differential Hermogravimetry (DTG) analysis using the multimodular thermal analyzer Netzsch STA 409 EP (Selb/Bayern, Germany). The samples were heated at a rate of $10{ }^{\circ} \mathrm{C} \cdot \mathrm{min}^{-1}$ under an air atmosphere (flow rate $100 \mathrm{~cm}^{3} \cdot \mathrm{min}^{-1}$ ) from 25 to $1200{ }^{\circ} \mathrm{C}$. The $\alpha-\mathrm{Al}_{2} \mathrm{O}_{3}$ crucibles were used without a lid.

\subsection{SAMPLES PREPARATION}

Five grams of milled vermiculite samples (Ver-B and Ver-SL) were mixed with $250 \mathrm{ml}$ of 0.5 or $1 \mathrm{M}$ 

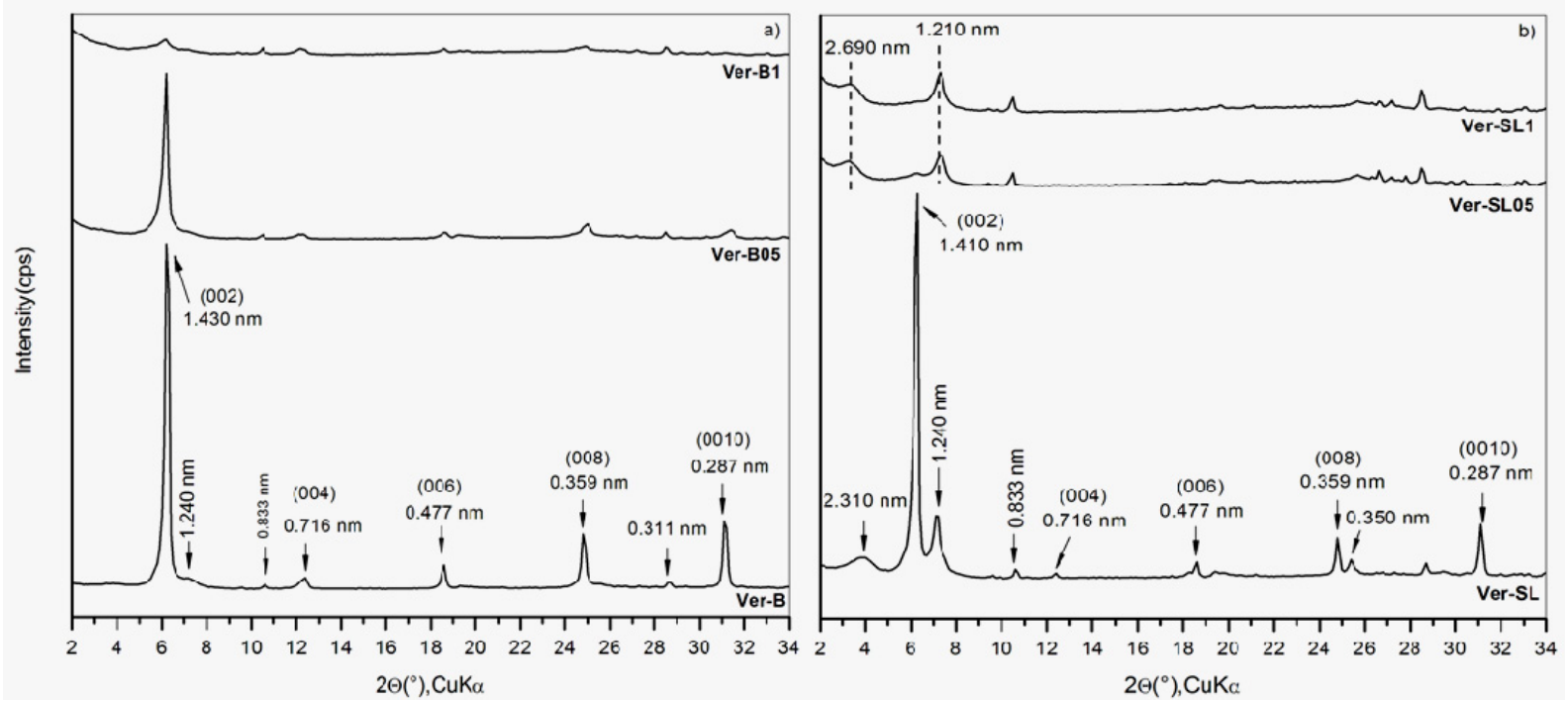

Fig. 1 XRD patterns of Ver-B (a) and Ver-SL (b) before and after acid treatments.

$\mathrm{HCl}$ solutions. The suspensions were stirred and heated at $80{ }^{\circ} \mathrm{C}$ for $4 \mathrm{~h}$. Then, the liquid portions were separated using centrifugation (5702 Eppendorf AG, Germany) $\left(3800 \mathrm{~min}^{-1}, 5 \mathrm{~min}\right.$ ). The solid precipitates were washed five times with demineralized water until they were chloride free, and air-dried at $80^{\circ} \mathrm{C}$ overnight. The resulting samples were labelled Ver-B05, Ver-B1, Ver-SL05 and Ver-SL1, according to acid concentration.

\section{RESULTS AND DISCUSSION}

\subsection{CHARACTERIZATION OF UNTREATED AND ACIDIFIED SAMPLES}

The chemical composition of untreated vermiculites (Ver-B and Ver-SL) was recalculated into structural formulae using a basis of 10 structural oxygens plus two $\mathrm{OH}$ and a total negative charge of 22 per formula unit (Köster, 1977), as follows:

$$
\begin{aligned}
& \text { Ver-B: }\left(\mathrm{Si}_{3.12} \mathrm{Al}_{0.88}\right)^{0.88-}\left(\mathrm{Al}_{0.01} \mathrm{Fe}_{0.36}^{3+} \mathrm{Fe}_{0.05}^{2+} \mathrm{Mg}_{2.56} \mathrm{Ti}_{0.02}\right)^{0.41+} \mathrm{O}_{10}(\mathrm{OH})_{2} \mathrm{Mg}_{0.09} \mathrm{Ca}_{0.11} \mathrm{~K}_{0.05} \mathrm{Na}_{0.02} \\
& \text { Ver-SL: }\left(\mathrm{Si}_{3.12} \mathrm{Al}_{0.88}\right)^{0.88-}\left(\mathrm{Al}_{0.05} \mathrm{Fe}_{0.37}^{3+} \mathrm{Fe}_{0.03}^{2+} \mathrm{Mg}_{2.50} \mathrm{Ti}_{0.05}\right)^{0.52+} \mathrm{O}_{10}(\mathrm{OH})_{2} \mathrm{Ca}_{0.07} \mathrm{~K}_{0.17} \mathrm{Na}_{0.05} .
\end{aligned}
$$

The loss on ignition of 17.0 and 15.7 wt.\% for untreated Ver-SL and Ver-B, respectively, and the presence of a higher amount of $\mathrm{K}_{2} \mathrm{O}(\sim 1.8 \mathrm{wt} . \%)$ in sample Ver-SL in comparison to Ver-B $(\sim 0.5 \mathrm{wt} . \%)$, respectively, suggest that the vermiculite samples are not pure Mg- vermiculites. Comparison of the structural formulae shows that only slight differences exist between the two vermiculite samples. Sufficient aluminum is present to be allocated to both tetrahedral and octahedral positions. The remaining octahedral positions are occupied primarily by magnesium along with iron and titanium. The interlayer positions are occupied by calcium and minor amount of magnesium in Ver-B sample and no magnesium but potassium in Ver-SL sample. The layer charge in the unit cell is slightly lower for Ver-SL (0.36) than for Ver-B (0.47). The low layer unit and interlayer charges in these and many of the other vermiculite formulas may be due to oxidation of $\mathrm{Fe}^{2+}$ to $\mathrm{Fe}^{3+}$. Such oxidation would increase the positive octahedral charge by an amount equivalent to the amount of bivalent iron oxidized and result in an equivalent decrease in the negative layer unit and positive interlayer charges (Foster, 1963).

The XRD pattern of natural sample Ver-B (Fig. 1a) shows an intense (002) basal reflection. The interlayer space value $d(002)=1.430 \mathrm{~nm}$ and successive basal reflections with the corresponding values $d(004)=0.716$ $\mathrm{nm}, d(006)=0.477 \mathrm{~nm}, d(008)=0.359 \mathrm{~nm}$ and $d(010)=0.287 \mathrm{~nm}$ represent the regular 2:1 layered structure of $\mathrm{Mg}$-vermiculite with the interlayer water network of two layers around the cations in the interlayer space (Shirozu and Bailey, 1966; Walker, 1956). Very low intense reflection with $d=1.240 \mathrm{~nm}$ may be from the lower thickness of water molecules between successive silicate layers (Walker, 1956), one-water-layer phase in interlayered domains (Marcos et al., 2009).

The basal (002) reflection in vermiculite sample Ver-SL (Fig. 1b) shows a slightly lower $d(002)=1.410 \mathrm{~nm}$ in comparison with the Ver-B sample. This small difference is probably associated with the occupation of the interlayer by different cations and the arrangement of water molecules around cations. The reflection with $d=$ $1.240 \mathrm{~nm}$ arising from the domains containing one-water layers is also present. A low-intensity, broad reflection with $d=2.310 \mathrm{~nm}$ has been assigned to the superstructure corresponding to the large number of a mixed-layer phase (e.g. random stratification of $1.4 \mathrm{~nm}$ and $1.2 \mathrm{~nm}$ layers) (Walker, 1956; Marcos et al., 2003; Valášková et al., 2013a). 
Table 1 The content of $\mathrm{SiO}_{2}, \mathrm{MgO}, \mathrm{Al}_{2} \mathrm{O}_{3}, \mathrm{Fe}_{2} \mathrm{O}_{3}$ and $\mathrm{K}_{2} \mathrm{O}$ and textural properties in untreated and acidified vermiculite samples.

\begin{tabular}{|c|c|c|c|c|c|c|c|}
\hline \multirow[t]{2}{*}{ Samples } & \multicolumn{5}{|c|}{ Chemical composition } & \multicolumn{2}{|c|}{ Textural properties } \\
\hline & $\mathrm{SiO}_{2}$ & MgO & $\mathrm{Al}_{2} \mathrm{O}_{3}$ & $\mathrm{Fe}_{2} \mathrm{O}_{3}$ & $\mathbf{K}_{2} \mathbf{O}$ & SA & $\mathbf{V p}$ \\
\hline \multicolumn{6}{|c|}{ (wt.\%) } & $\left(\mathrm{m}^{2} \cdot \mathrm{g}^{-1}\right)$ & $\left(\mathrm{cm}^{3} \cdot \mathrm{g}^{-1}\right)$ \\
\hline Ver-B & 41.2 & 23.2 & 10.0 & 6.2 & 0.5 & 29.5 & 0.040 \\
\hline Ver-B05 & 53.8 & 14.8 & 6.6 & 4.6 & 0.5 & 261 & 0.184 \\
\hline Ver-B1 & 60.3 & 11.8 & 4.7 & 4.2 & 0.4 & 273 & 0.187 \\
\hline Ver-SL & 43.3 & 23.2 & 10.8 & 6.7 & 1.8 & 14.0 & 0.026 \\
\hline Ver-SL05 & 56.1 & 10.7 & 6.9 & 5.4 & 1.7 & 191 & 0.124 \\
\hline Ver-SL1 & 61.4 & 9.8 & 6.2 & 4.8 & 1.6 & 226 & 0.146 \\
\hline
\end{tabular}

Both the vermiculite samples represent a mixedlayer structure after incomplete transformation of mica (biotite) to vermiculite. Based on the X-ray diffraction patterns, Ver-B may be considered as the mixed-layer vermiculite interstratified with small proportion of mica layers and Ver-SL as the mixedlayer mica-vermiculite.

The XRD patterns of the acidified samples, as compared to their untreated samples (Fig. 1), show a significant reduction in intensities of the basal reflections, which is evidence for a low amount of the layers in stratified sequence. The basal (002) reflection was reduced in intensity by about $52 \%$ in Ver-B05 and about $95 \%$ in Ver-B1 as compared to the Ver-B (Fig. 1a); it was strongly reduced in VerSL05 and disappeared in Ver-SL1. The reflection with the interlayer value $d=1.240 \mathrm{~nm}$ in Ver-SL was slightly changed to $d=1.210 \mathrm{~nm}$ in Ver-SL05 and Ver-SL1, probably due to water layer disordering during acid treatment. The reflection $d=2.310 \mathrm{~nm}$ in Ver-SL of the mixed-layer phase is similar to the VerB. In acid treated samples increased to $d=2.690 \mathrm{~nm}$ in Ver-SL05 and Ver-SL1. The values corresponds to the mixed-layer phase in the large number of higher orders (probably with $d=1.240 \mathrm{~nm}+d=1.420 \mathrm{~nm}$ ) (Walker, 1956; Marcos et al., 2009; Valášková et al., 2014).

\subsection{CHEMICAL COMPOSITION}

The two vermiculites and their acid treated samples revealed different changes in their chemical composition, values of surface area (SA) and pore volume (Vp) (Table 1). According to the elemental analysis, the content of $\mathrm{MgO}$ was about 23 wt. $\%$ at both Ver-B and Ver-SL samples (Table 1). The remaining content decreased in leached samples VerB05 and Ver-B1 to $64 \%$ and $51 \%$, respectively, and more significantly decreased to $46 \%$ and $42 \%$ in Ver-SL05 and Ver-SL1 samples, respectively. Leaching of the octahedral cations $\mathrm{Fe}^{3+}$ did not prevail over tetrahedral $\mathrm{Al}^{3+}$ and their oxides decreased in the Ver-B05 to $74 \%$ and $66 \%$, respectively, in Ver-SL05 to $81 \%$ and $64 \%$, respectively, in Ver-B1 to $68 \%$ and $47 \%$ and in Ver-SL1 to $72 \%$ and $57 \%$, respectively. The $\mathrm{K}_{2} \mathrm{O}$ content was maintained in VerB05 and slightly decreased in Ver-B1 in comparison to untreated Ver-B. Similarly, the $\mathrm{K}_{2} \mathrm{O}$ content was decreased in comparison with the Ver-SL by about $6 \%$ in Ver-SL05 and about $11 \%$ in Ver-SL1. Taking into account that Ver-B and Ver-SL have very similar chemical composition in $\mathrm{Al}_{2} \mathrm{O}_{3}$ and $\mathrm{Fe}_{2} \mathrm{O}_{3}$, we can state that the interstratified vermiculite Ver-SL1, in comparison with vermiculite Ver-B1, showed lower leaching ability of $\mathrm{Al}^{3+}$ from the tetrahedral sites and of $\mathrm{Fe}^{3+}$ from the octahedral sites.

\subsection{PHYSICAL PROPERTIES}

The surface area (SA) values for untreated Ver-B and for Ver-SL samples, prepared in the less than $40 \mu \mathrm{m}$ size fraction, were $29.5 \mathrm{~m}^{2} \cdot \mathrm{g}^{-1}$ and $14.0 \mathrm{~m}^{2} \cdot \mathrm{g}^{-1}$, respectively. The $0.5 \mathrm{M} \mathrm{HCl}$ acid treatment for $4 \mathrm{~h}$ had a significant influence on the SA values, which increased to $261 \mathrm{~m}^{2} \cdot \mathrm{g}^{-1}$ in Ver-B05 and $191 \mathrm{~m}^{2} \cdot \mathrm{g}^{-1}$ in Ver-SL05. The SA obtained by $0.5 \mathrm{M} \mathrm{HCl}$ leaching of vermiculites Ver-B and Ver-SL are higher than the value $90.95 \mathrm{~m}^{2} . \mathrm{g}^{-1}$ obtained by Maqueda et al. (2007) for $<80 \mu \mathrm{m}$ vermiculite particles from Santa Olalla (Spain) and slightly lower than the value $299 \mathrm{~m}^{2} . \mathrm{g}^{-1}$ reported by Temuujin et al. (2003) for $<500 \mu \mathrm{m}$ vermiculite particles from South Africa. After the $1 \mathrm{M}$ $\mathrm{HCl}$ treatment, the $<40 \mu \mathrm{m}$ vermiculite particles showed SA values $273 \mathrm{~m}^{2} \cdot \mathrm{g}^{-1}$ for Ver-B1 and $226 \mathrm{~m}^{2} . \mathrm{g}^{-1}$ for Ver-SL1. Both values are considerably lower than the $504.3 \mathrm{~m}^{2} \cdot \mathrm{g}^{-1}$ reported for Santa Olalla vermiculite (Maqueda et al. 2007) and $553 \mathrm{~m}^{2} \cdot \mathrm{g}^{-1}$ for South African vermiculite (Temuujin et al., 2003). The increase in the value of SA was already evident after exposure to $0.5 \mathrm{M} \mathrm{HCl}$, while $1 \mathrm{M}$ concentration no longer significantly contributed to an increase in the surface area. Different values SA between VerB05 and Ver-SL05 were influenced by the nature of the cations in the interlayer and $\mathrm{Mg}^{2+}$ in the octahedra, which were leached into the water. Thus leached interlayer cations of $\mathrm{Ca}^{2+}$ and $\mathrm{Mg}^{2+}$ from the interlayer of Ver-B contributed the greatest increase in surface of Ver-B05.

The cations leached from vermiculite interlayer and octahedra also influenced the pore size distribution. The pore-size distributions (PSD) of the untreated Ver-B and Ver-SL (Fig. 2) are bimodal (two maxima at $10-50 \mathrm{~nm}$ and $>300 \mathrm{~nm}$ ); after leaching they became unimodal, with a maximum in the $10-$ 

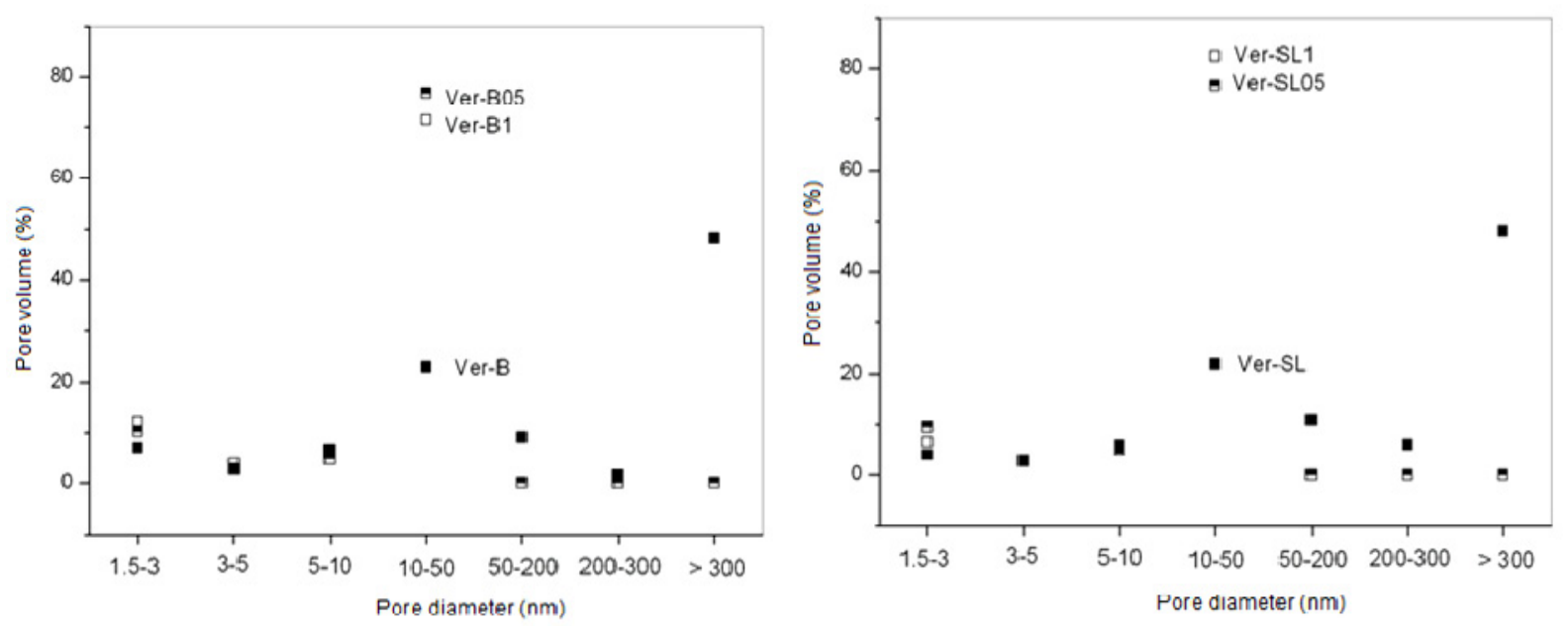

Fig. 2 PSD of vermiculites from a) Brazil (Ver-SL) and b) Bulgaria (Ver-B) before and after acid treatments.
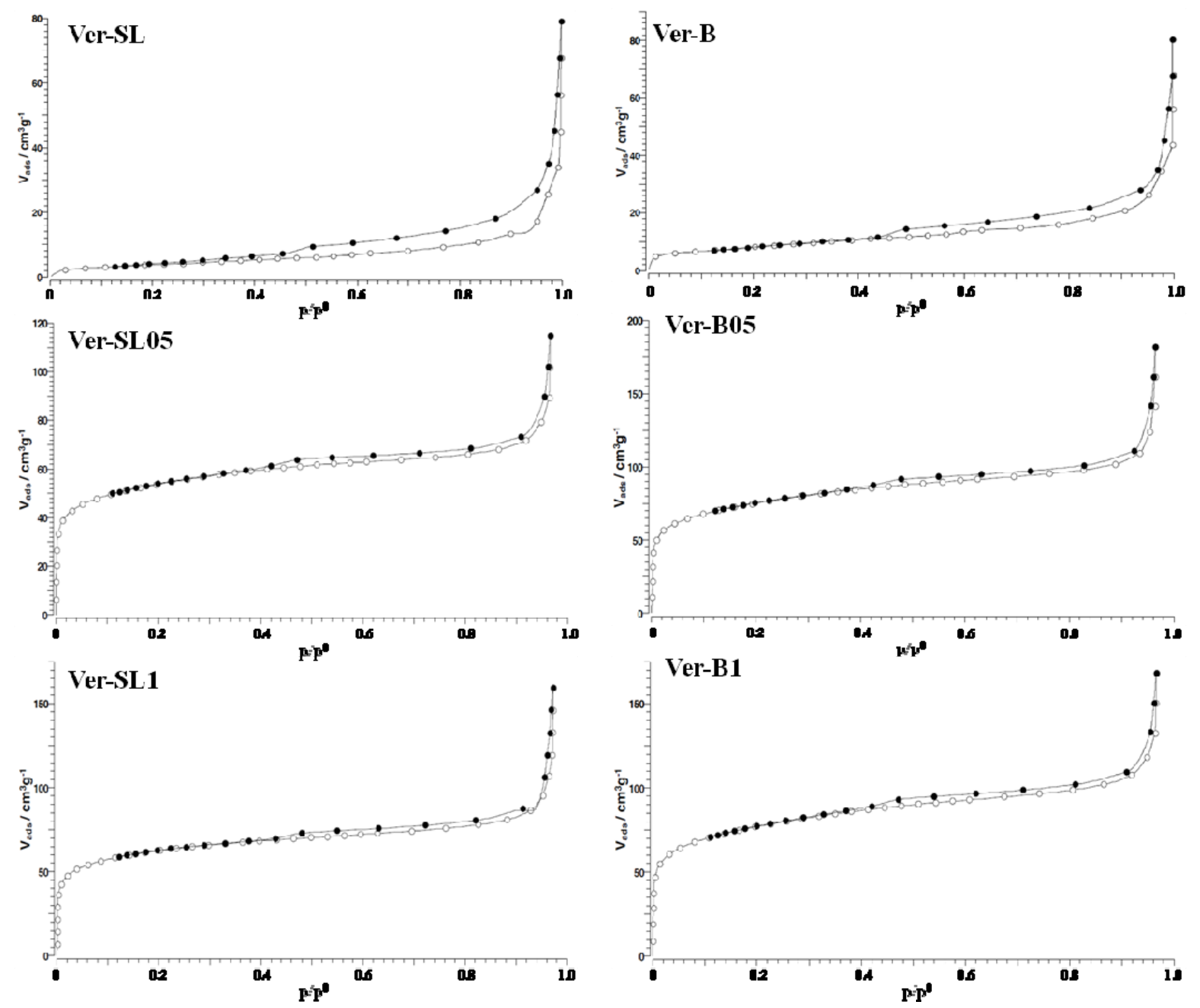

Fig. 3 Nitrogen adsorption-desorption isotherms of natural and acid treated vermiculite samples. 
Table 2 The thermogravimetric data of untreated and acidified vermiculite samples.

\begin{tabular}{|c|c|c|c|c|c|c|c|}
\hline \multirow[t]{3}{*}{ Sample } & \multicolumn{7}{|c|}{ Decomposition intervals } \\
\hline & \multirow[b]{2}{*}{$(\mathrm{mg})$} & \multicolumn{2}{|l|}{1} & \multicolumn{2}{|l|}{2} & \multicolumn{2}{|l|}{3} \\
\hline & & $\begin{array}{l}\Delta \mathrm{T}_{1} \\
\left({ }^{\circ} \mathrm{C}\right)\end{array}$ & $\begin{array}{l}\Delta \mathrm{m}_{1} \\
(\mathrm{mg})\end{array}$ & $\begin{array}{l}\Delta \mathrm{T}_{2} \\
\left({ }^{\circ} \mathrm{C}\right)\end{array}$ & $\begin{array}{l}\Delta \mathrm{m}_{2} \\
(\mathrm{mg})\end{array}$ & $\begin{array}{l}\Delta \mathrm{T}_{3} \\
\left({ }^{\circ} \mathrm{C}\right)\end{array}$ & $\begin{array}{l}\Delta \mathrm{m}_{3} \\
(\mathrm{mg})\end{array}$ \\
\hline Ver-B & 36.0 & $22-185$ & 2.5 & $185-280$ & 0.7 & $280-700$ & 1.1 \\
\hline Ver-B05 & 33.8 & $18-270$ & 2.4 & - & - & $270-700$ & 1.0 \\
\hline Ver-B1 & 29.4 & $31-210$ & 1.7 & - & - & $270-700$ & 1.2 \\
\hline Ver-SL & 38.8 & $27-185$ & 2.9 & $185-280$ & 0.7 & $280-700$ & 0.6 \\
\hline Ver-SL05 & 35.2 & $17-270$ & 2.1 & - & - & $280-700$ & 0.8 \\
\hline Ver-SL1 & 32.8 & $29-210$ & 2.1 & - & - & $280-700$ & 0.9 \\
\hline
\end{tabular}
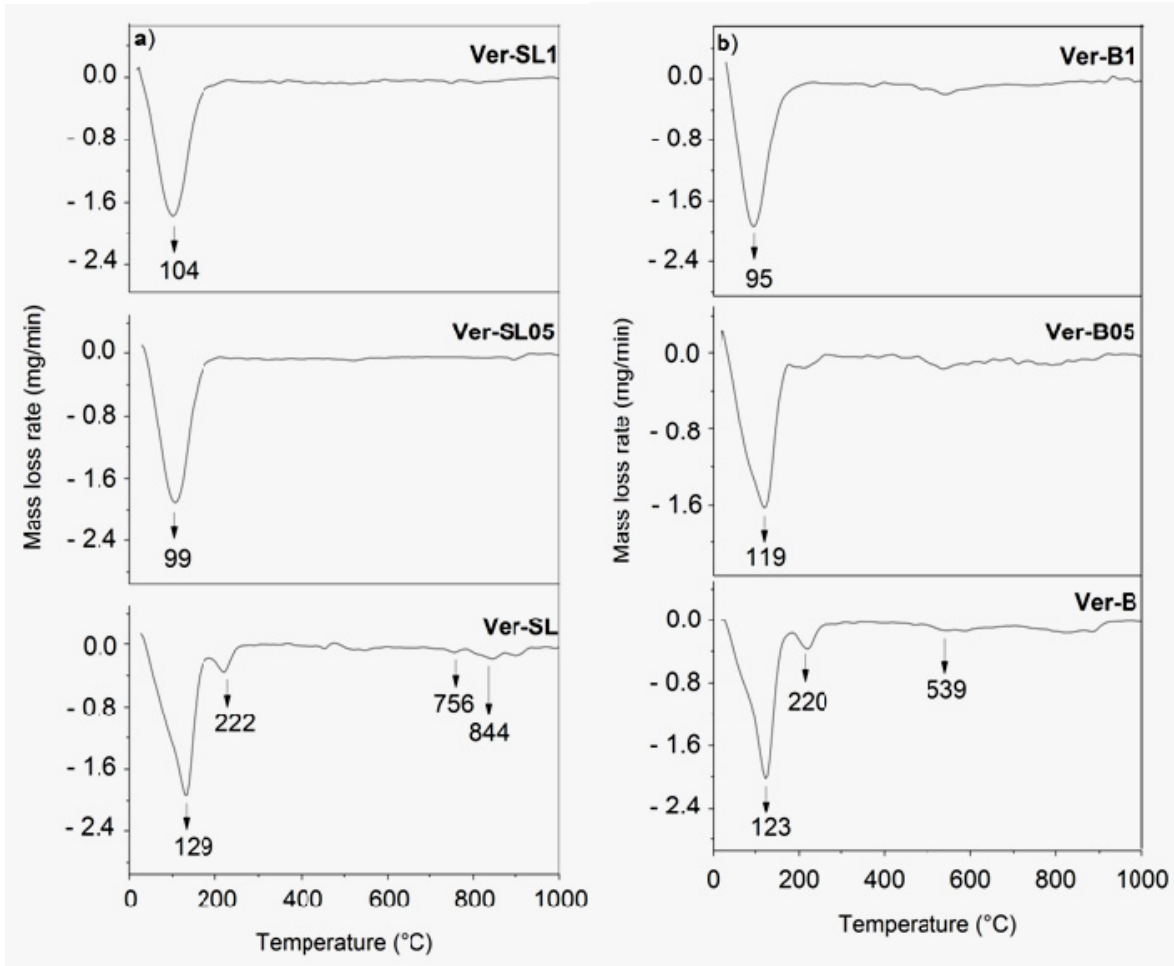

Fig. 4 DTG curves of a) Ver-SL, Ver-SL05, Ver-SL1 and b) Ver-B, Ver-B05 and Ver-B1.

$50 \mathrm{~nm}$ range. The pore size distribution of Ver-B and Ver-SL (Fig. 2) indicates that the studied samples contain mainly macropores (about $62 \%$ ) which prevail over mesopores $(\sim 34 \%)$ and a negligible content of micropores $(\sim 4 \%)$. All acidified samples contained a higher volume of mesopores (approximately $89 \%$ in Ver-B05 and VerB1, and around $93 \%$ in Ver-SL05 and Ver-SL1) than micropores (10 and $12 \%$ in Ver-B05 and Ver-B1, respectively, and 10 and $6 \%$ in Ver-SL05 and VerSL1, respectively). These findings were also confirmed according to the shapes of the nitrogen adsorption-desorption isotherms for natural and acidactivated vermiculites (Fig. 3). The presence of mesopores was revealed by the small hysteresis loops that appear in all isotherms.

\subsection{THERMAL ANALYSIS}

The DTA and DTG curves showed the first (T1) and second (T2) endothermic effects of dehydration in vermiculites (Fig. 4) at 123 and $220^{\circ} \mathrm{C}$ at Ver-B and 129 and $222{ }^{\circ} \mathrm{C}$ at Ver-SL, which correspond to the loss of water molecules adsorbed with different strengths in the interlayer around the cations (Gaudette, 1964). The sum of the mass loss in the two stages $\left(\Delta \mathrm{m}_{1}, \Delta \mathrm{m}_{2}\right.$ in Table 2$)$ in the thermal intervals $\mathrm{T} 1$ and T2 was 8.9 and $9.3 \%$ at Ver-B and Ver-SL, respectively.

One endothermic effect (T1) at all acidified vermiculite samples was always below T1 of their untreated vermiculite samples (Fig. 4). The maxima of $\mathrm{T} 1$ at Ver-B05 and Ver-B1 were indicated at $119^{\circ} \mathrm{C}$ and $95{ }^{\circ} \mathrm{C}$, respectively, i.e. about $4{ }^{\circ} \mathrm{C}$ and $28{ }^{\circ} \mathrm{C}$ 
lower in comparison with the $\mathrm{T} 1$ at Ver-B. The mass loss in the thermal interval $\Delta \mathrm{m}_{1}$ was $7.1 \%$ and $5.8 \%$ at Ver-B05 and Ver-B1, respectively. The maxima of $\mathrm{T} 1$ at Ver-SL05 and Ver-SL1 at $104{ }^{\circ} \mathrm{C}$ and $99{ }^{\circ} \mathrm{C}$, respectively, were in comparison with the $\mathrm{T} 1$ at VerSL about $25^{\circ} \mathrm{C}$ and $30^{\circ} \mathrm{C}$ lower. The mass loss in the dehydration thermal interval $\Delta \mathrm{m}_{1}$ was $6.0 \%$ and $6.4 \%$ at Ver-SL05 and Ver-SL1, respectively. Very broad and weak endothermic effect at about $539{ }^{\circ} \mathrm{C}$ has been attributed to the dehydroxylation of Ver-B and its acidified samples. The endothermic effects at $756{ }^{\circ} \mathrm{C}$ and $844{ }^{\circ} \mathrm{C}$ at Ver-SL and its acidified samples may correspond to the melting (Guggenheim and Koster van Groos, 2001) (Fig. 4).

\section{CONCLUSIONS}

Structures of two natural vermiculites (Ver) with the very similar chemical composition but slightly different low charge on the layers were characterized on their particle size fraction less than $40 \mu \mathrm{m}$ after treatment with different hydrochloric acid concentrations $(0.5 \mathrm{M} \mathrm{HCl}$ and $1 \mathrm{M} \mathrm{HCl})$.

According to the X-ray diffraction analysis, the Ver-B sample was characterized as the mixed-layer vermiculite with small proportion of mica layers and Ver-SL sample as the mixed-layer mica-vermiculite. Changes of chemical composition after acid leaching have been studied in relation to the structure of vermiculite. The interstratified vermiculite Ver-SL1, showed lower leaching ability of $\mathrm{Al}^{3+}$ from the tetrahedral sites and of $\mathrm{Fe}^{3+}$ from the octahedral sites than vermiculite Ver-B1. Changes in surface area increase and the pore size distribution were dependent on the structure and leaching ability of cations from the interlayer and octahedra. Dehydration of mixedlayer vermiculites were observed at the two endothermic effects. All acidified samples dehydrated in the first endothermic effect and at lower temperature than it was determined at untreated vermiculite samples.

\section{ACKNOWLEDGEMENTS:}

The financial support of the IT4Innovations (no. cz.1.05/1.1.00/02.0070), and the Nanotechnology - the basis for international cooperation (no. cz.1.07/2.3.00/20.0074) are gratefully acknowledged. Authors thank S. Studentová for the SA measurement and D. Casten for polishing the English text.

\section{REFERENCES}

Alves, A.P.M., Fonseca, M.G. and Wanderley, A.F.: 2013, Inorganic-organic hybrids originating from organosilane anchored onto leached vermiculite. Mater. Res., 16, 891-897. DOI: $10.1590 / \mathrm{S} 1516-14392013005000076$

Brigatti, M.F., Galan, E. and Theng, B.K.G.: 2006, Handbook of Clay Science, Developments in Clay Science: Bergaya, F., Theng, B.K.G., Lagaly G. (Eds.): Elsevier, Amsterdam, 1, Chapter 2, 19-86.
Foster, M.D.: 1963, Interpretation of the composition of vermiculites and hydrobiotites. Clays Clay Miner., 10, $70-89$.

Gaudette, H.E.: 1964, Magnesium vermiculite from the Twin Sisters Mountains, Washington. Am. Miner., 49, 1754-1763.

Guggenheim, S. and Koster van Groos, A.F.: 2001, Baseline studies of the clay minerals society source clays: thermal analysis. Clays Clay Miner., 49, 433-443.

Guggenheim, S., Alietti, A., Drits, V.A., Formoso, M.L.L., Galán, E., Köster, H.M., Paquet, H., Watanabe, T., Bain, D.C. and Hudnall, W.H.: 1997, Report of the Association Internationale Pour l'Etude des Argiles (AIPEA) Nomenclature committee for 1996. Clays Clay Miner., 45, 298-300.

Jin, L. and Dai, B: 2012, $\mathrm{TiO}_{2}$ activation using acid-treated vermiculite as a support: characteristics and photoreactivity. Appl. Surf. Sci., 258, 3386-3392. DOI: $10.1016 /$ j.apsusc. 2011.11 .017

Köster, H.M.: 1977, Die Berechnung kristallchemischer Strukturformeln von 2:1-Schichtsilikaten unter Berucksichtigung der gemessengen Zwischenschichtladungen und Kationenumtauschkapazitäten, sowie die Darstellung der Ladungsverteilung in der Struktur mittels Dreieckskoordinaten. Clay Miner., 12, 45-54.

Kumar, S., Panda, A.K. and Singh, R.K.: 2013, Preparation and characterization of acids and alkali treated kaolin clay. Bull. Chem. React. Eng. Catal. 8, 61-69.

Lagaly, G.: 1982, Layer charge heterogeneity in vermiculites. Clays Clay Miner. 30, 215-222.

Maqueda, C., Romero, A.S., Morillo, E. and PérezRodriguez, J.L.: 2007, Effect of grinding on the preparation of porous materials by acid-leached vermiculite. J. Phys. Chem. Sol., 68, 1220-1224. DOI: $10.1016 /$ j.jpcs.2007.01.037

Maqueda, C., Romero, A.S., Morillo, E., Pérez-Rodriguez, J.L., Lerf, A. and Wagner, F.E.: 2008, The behavior of $\mathrm{Fe}$ in ground and acid-treated vermiculite from Santa Olalla, Spain. Clays Clay Miner., 56, 380-388. DOI: 10.1346/CCMN.2008.0560307.

Marcos, C., Argüelles, A., Ruiz-Conde, A., Sánchez-Soto, P.J. and Blanco, J.A.: 2003, Study of the dehydration process of vermiculites by applying a vacuum pressure: formation of interstratified phases. Mineral. Mag., 67, 1253-1268. DOI: $10.1180 / 0026461036760163$

Marcos, C., Arango, Y.C. and Rodriguez, I.: 2009, X-ray diffraction studies of the thermal behavior of commercial vermiculites. Appl. Clay Sci., 42, 368378. DOI: $10.1016 /$ j.clay.2008.03.004

Meunier, A.: 2005, Clays. Springer-Verlag, Berlin Heidelberg.

Moore, D.M. and Reynolds, R.C.: 1997, X-ray diffraction and the identification and analysis of clay minerals. New York: Oxford University Press, Oxford.

Perez-Maqueda, L.A., Maqueda, C., Perez-Rodriguez, J.L., Subrt, J., Cerny, Z. and Balek, V.: 2012, Thermal behaviour of ground and unground acid leached vermiculite. J. Therm. Anal. Calorim., 107, 431-438. DOI: $10.1007 / \mathrm{s} 10973-011-1480-2$

Santos, S.S.G., Silva, H.R.M., de Souza, A.G., Alves, A.P.M., da Silva Filho, E.C. and Fonseca, M.G.: 2015, Acid-leached mixed vermiculites obtained by treatment with nitric acid. Appl. Clay Sci., 104, 286294. 
Schoeman, J.J.: 1989, Mica and vermiculite in South Africa. J. S. Afr. Inst. Min. Metall. 89, 1-12.

Seghedi, A.: 2012, Palaeozoic formations from Dobrogea and Pre-Dobrogea an Overview. Turk. J. Earth Sci, 21, 669-721.

Seidlerová, J., Otoupalíková, H. and Nováčková, M.: 2007, Kinetics of leaching of pollutants from metallurgical wastes. Chem. Pap., 101, 165-170.

Shirozu, H. and Bailey, S.W.: 1966, Crystal structure of a two-layer Mg-vermiculite. Am. Mineral., 77, 904910.

Suquet, H., Chevalier, S., Marcilly, C. and Barthomeuf, D.: 1991, Preparation of porous materials by chemical activation of the Llano vermiculite. Clay Miner., 26, 49-50.

Temuujin, J., Okada, K. and MacKenzie, K.J.D.: 2003, Preparation of porous silica from vermiculite by selective leaching. Appl. Clay Sci., 22, 187-195. DOI:10.1016/S0169-1317(02)00158-8.

Temuujin, J., Minjigmaa, A., Jadambaa, TS., Tsend-Ayush, S. and MacKenzie, K.J.D.: 2008, Porous properties of silica prepared by selective acid leaching of heattreated vermiculite. Chem. Subst. Develop., 16, 223227.

Valášková, M., Tokarský, J., Čech Barabaszová, K., Matějka, V., Hundáková, M., Pazdiora, E and Kimmer, D.: 2013a, New aspects on vermiculite filler in polyethylene. Appl. Clay Sci., 72, 110-116. DOI: $10.1016 /$ j.clay.2012.12.005

Valášková, M., Tokarský, J., Hundáková, M., Zdrálková, J. and Smetana, B.: 2013b, Role of vermiculite and zirconium-vermiculite on the formation of zirconcordierite nanocomposites. Appl. Clay Sci. 75-76, 100-108. DOI: 10.1016/j.clay.2013.02.015

Valášková, M., Zdrálková, J., Simha Martynková, G., Smetana, B., Vlček, J. and Študentová, S.: 2014, Structural variability of high purity cordierite/steatite ceramics sintered from mixtures with various vermiculites. Ceram. Int., 40, 8489-8498. DOI: $10.1016 /$ j.ceramint.2014.01.060

Walker, G.F.: 1956, The mechanism of dehydration of Mgvermiculite. Clays Clay Miner., 4, 101-115.

Wiewióra, A., Perez-Rodriguez J.L., Perez-Maqueda, L.A., Drapala, J.: 2003, Particle size distribution in sonicated high- and low-charge vermiculites. Appl. Clay Sci., 24, 51-58.

DOI: $10.1016 / \mathrm{S} 0169-1317(03) 00133-9$ 